\title{
Impact of Exchange Rate Volatility on Unemployment in South Africa
}

\author{
Olivia Nyahokwe \\ University of Fort Hare \\ Private Bag X1314, Alice,5700 nyahokweolivia@gmail.com, \\ Prof. R. Ncwadi \\ PhD (Economics), Deputy Dean (Research \& Internationalisation) \\ Faculty of Management \& Commerce, University of Fort Hare \\ Private Bag X1314, Alice, 5700 \\ Tel: 040-6022214; Fax: 0866216902, Mobile: 0826822287/0768343614
}

\section{Doi:10.5901/mjss.2013.v4n3p109}

\begin{abstract}
Real exchange rate volatility have important effects on production, employment and trade, so it is crucial to understand its impact on unemployment especially on a country like South Africa. This article analyses the impact of the real exchange rate volatility on unemployment and the dynamic adjustment of unemployment rate following shocks to its determinants using quarterly South African data covering the period 2000 to 2010. This article augments the cointegration and vector autoregression (VAR) and the GARCH model including analysis with impulse response and variance decomposition analyses to provide robust long run effects and short run dynamic effects on the unemployment rate. The empirical analysis using a variety of specifications, estimation techniques, and robustness tests suggests that exchange rate volatility has a statistically and economically significant impact on employment. The variables that have been found to have a long run relationship with unemployment rate include the real exchange rate, exports, real interest rate and the gross domestic product. The impulse response functions broadly corroborate the theoretical predictions, but only real interest rate and exports have a significant impact on unemployment in the short run. Results from the variance decompositions are largely similar to those from the impulse response analysis. The real exchange rate and exports are the only variables found to significantly explain the variation in the unemployment. The most interesting result that emerged from this analysis and is supported by previous research is that among other determinants, the real exchange rate explain the largest proportion of the variation in unemployment rate. On balance, the evidence therefore suggests that unemployment rate fluctuations are predominantly equilibrium responses to real exchange rate shocks in comparison with interest rates, economic growth and exports.
\end{abstract}

Keywords: real exchange rate volatility, unemployment,GARCH,vector autoregression

\section{Introduction}

Increasing capital market integration following the end of the Bretton Woods system and the accompanying financial liberalization wave of 1980s and early 1990s exposed both developed and developing countries to large swings in exchange rates. As a result, the effects of exchange rate volatility on investment and growth have increasingly become of particular interest to both researchers and policy makers. In many empirical studies, increasing uncertainty and volatility in exchange rates are found to have an effect on the profits of the firms, investments, economic growth as well as on international trade in both developed and developing countries (Aizenmann and Marion, 1999 and Serven, 1988).

However, little research has been done on the effects of exchange rate volatility on unemployment. Dixit,(1989) explains that empirical research on the employment effects of exchange rate volatility has mainly been focused on developed countries almost to the exclusion of developing countries. The limited nature of research on developing countries with respect to the impact of exchange rate volatility on unemployment in developing countries raises some concerns in that these countries face higher levels of unemployment (Mobarak, 2005, Pallage and Robe, 2003).

Of the few researchers who have conducted research on the effects of exchange rate volatility on unemployment are Andersen and Sorensen (1988) who argue that trade unions may impact the labour market negatively through their continuous call for wage hikes; which in turn leads to high inflation. Consequently the level of employment declines as a result of exchange rates volatility (Belke and Kaas,2004). According to Belke and Gros (2001), even a temporary 
increase in exchange rate volatility can induce firms to postpone the creation of jobs since volatile exchange rates raise the uncertainty of future earnings (Dixit,1989).

Volatile exchange rates may also increase unemployment through lowering investment in physical capital (Belke and Gros,2001). Investment may be reduced because higher volatility usually entails increased uncertainty. However, as Darby (1999) argues, the effect of exchange rate volatility on investment may either be negative or positive, depending on specific characteristics of the respective industry, for example some firms may benefit from a weak currency (exporting firms) whilst others benefit from a strong currency (importing firms).

\section{Methodology}

\subsection{GARCH Model}

The origins of the GARCH model can be found in the ARCH model which was developed by Engel in 1982. To describe data series with time varying volatility, an $\mathrm{ARCH}$ model allows the variance of error terms to change over time. Engel (1982) defined the $\varepsilon_{t}$ terms of the ARMA mean equation as an autoregressive conditional heteroskedastic (ARCH) process where all $\varepsilon_{t}$ are of the form:

$$
\begin{aligned}
& \varepsilon_{t}=z_{t} \sigma_{t} \\
& \text { and } \\
& \sigma_{t}^{2}=\omega+\sum_{i=1}^{\rho} \alpha_{i} \varepsilon_{t-i}^{2}
\end{aligned}
$$

Where $z_{t}$ is an independent and identically distributed (i.i.d) variable has a distribution with a zero mean and a unit variance (Piot-Lepeti and M'Barek, 2011:88). Although $\varepsilon_{t}$ is serially uncorrelated, its conditional variance $\sigma_{t}^{2}$ may change over time. However, the ARCH model has two shortcomings. Firstly, the ARCH (p) model is regarded as a short memory process because only recent $p$ residuals have an effect on the current variance. Secondly, it is important to note that the ARCH specification, according to Engel (1995), looked more like a moving average specification than an auto regression. The GARCH lets the conditional variance be a function of the squares of previous observations and past variances. It improves the autoregressive structure on conditional variance allowing shocks to persist over time. A $\operatorname{GARCH}(\mathrm{p}, \mathrm{q})$ model, therefore, models the variance equation as follows:

$$
\sigma_{t}^{2}=\omega+\sum_{i=1}^{p} \alpha_{i} \varepsilon_{t-i}^{2}+\sum_{j=1}^{q} \beta_{j} \sigma_{t-j}^{2}
$$

The GARCH $(\mathrm{p}, \mathrm{q})$ models an error term $\varepsilon_{t}$ in terms of a standard white noise $e_{t} \sim N(0,1)$ as:

$\varepsilon_{t}=\sqrt{\sigma_{t} e_{t}}$

In this way, the error term has a conditional variance that is a function of the magnitudes of past errors. The $p, q$ in the $\operatorname{GRACH}(p, q)$ mean that the conditional variance depends on the $p$ most recent squared residuals and the $q$ most recent conditional variances.

Piot-Lepeti and M'Barek $(2011: 88)$ holds that the GARCH $(p, q)$ model allows a longer memory process in which all the past residuals can affect the current variance either directly or indirectly through the lagged variance terms. GARCH estimates are used to identify periods of high volatility and high clustering. GARCH have become widespread tools for dealing with time series heteroskedastic models. The goal of such models is to provide a volatility measure of deviation which can be used in financial decisions concerning risk analysis, portfolio selection and derivative pricing. The goal of volatility analysis must ultimately be to explain the causes of volatility.

Many financial time series such as stock returns and exchange rates, exhibit changes in volatility in time and these changes tend to be serially correlated. Moreover, evidence shows the distribution of time series data such as exchange rates is characterized by leptokurtosis, fat tails, skewness and volatility clustering (Lee, 2003). The GARCH model accounts for fat tails, leptokurtosis and volatility clustering that are commonly associated with financial time series. Dowd (2005:132) argues that the GARCH model is tailor made for volatility clustering, and this clustering produces returns with fatter than normal tails even if the innovations- the random shocks are themselves normally distributed. Generally the presence of leptokurtic tendencies on the time series returns suggests the presence of volatility clustering; hence, the modelling of such phenomena is recommended through use of the GARCH. In the GARCH, effects such as volatility clustering and leptokurtosis are captured by letting the conditional variance be a function of the squares of previous observations and past variances.

The GARCH model in this article is utilized to determine the impact of the exchange rate volatility on unemployment in South Africa. Developed by Bollerslev (1987), GARCH (Generalized AutoRegressive Conditional 
Heteroscedastic) model is a class of non-linear models for the innovations $\left\{\mathcal{E}_{t}\right\}$, which allow the conditional innovation variance to be stochastic and dependent on the available information $\psi_{t-1}$ (Brook,2003).

According to the GARCH model, innovations are stationary, zero-mean, uncorrelated (but not independent) and the conditional volatility is a random variable defined in terms of present and past innovations and conditional volatilities. The GARCH $(\mathrm{p}, \mathrm{q})$ model for $\left\{e_{t}\right\}$ assumes $(\mathrm{p}, \mathrm{q})$ are not related to the orders $(k, 1)$ of the ARMA process which might be used to describe $\left\{x_{t}\right\}$ (Gujarati,2004). The advantage of GARCH models lies in their ability to describe the time-varying stochastic conditional volatility, which can then be used to improve the reliability of interval forecasts. The GARCH $(p, q)$ process is non-linear and the unconditional distribution of $e_{t}$ is not Gaussian. Thus, outliers may occur relatively often. Moreover, once an outlier occurs, it increases the conditional volatility for some time to come. This feature is a characteristic of many actual financial time series (Brook,2003).

The GARCH specification incorporates and handles well the frequently-observed financial time series behaviour such volatility clustering and skewness. Many financial time series such as the exchange rate exhibit changes in volatility in time and these changes tend to be serially correlated. GARCH model accounts for fat tails, leptokurtosis and volatility clustering that are commonly associated with financial time series.

The variable of interest in this article uses $\operatorname{GARCH}(1,1)$ to test the volatility of real exchange rate quarterly data. GARCH measure of conditional volatility is a good proxy for uncertainty since it measures the variance of the stochastic, unpredictable component of a variable. GARCH is also superior to unconditional measures such as the standard deviation since the latter ignores relevant information on the random process generating the exchange rate. Therefore, the measure of exchange rate volatility using $\mathrm{GARCH}$ is better suited than using a standard deviation of exchange rate (Feldmann,2011).

One of the assumptions of the least squares model is that the expected value of all error terms, when squared, is the same at any given point. This assumption is called homoskedasticity. When the expected value of all error terms, when squared, is not the same there would be the problem of heteroscedasticity.

Engel (2001) notes that "data in which the variances of the error terms are not equal, in which the error terms may reasonably be expected to be larger for some points or ranges of the data than for others, are said to suffer from heteroskedasticity. Instead of considering this as a problem to be corrected, GARCH models treat heteroskedasticity as a variance to be modelled. As a result, not only are the deficiencies of least squares corrected, but a prediction is computed for the variance of each error term.

\subsection{Vector autoregressive model}

Vector autoregressive models (VARs) were popularised in econometrics by Sims (1980) as a natural generalisation of univariate autoregressive models. A VAR is a systems regression model (i.e. there is more than one dependent variable) that can be considered a kind of hybrid between the univariate time series models and the simultaneous equations models. VARs have often been advocated as an alternative to large-scale simultaneous equations structural models. An important feature of the VAR model is its flexibility and the ease of generalisation. A useful facet of VAR models is the compactness with which the notation can be expressed. For example, $k=1$, so that each variable depends only upon the immediately previous values of $y_{1 t}$ and $y_{2 t}$, plus an error term (Brook, 2003).

The VAR model can estimate a vibrant simultaneous equation system without putting any prior restrictions on the structure of the relationships. Because it does not have any structural restrictions, the VAR system enables the estimation of a reduced form of correctly specified equations whose actual economic structure may be unknown.

VAR models have several advantages compared with univariate time series models or simultaneous equations structural models, for example a researcher does not need to specify which variables are endogenous or exogenous. All variables are endogenous. This is an important point, since a requirement for simultaneous equations structural models to be estimable is that all equations in the system are identified. Essentially, this requirement boils down to a condition that some variables are treated as exogenous and that the equations contain different right hand side variables.

VAR models allows the value of a variable to depend on more than just its own lags or combinations of white noise terms. Therefore VARs are more flexible than univariate autoregressive models; the latter can be viewed as a restricted case of VAR models.VAR models can therefore offer a very rich structure, implying that they may be able to capture more features of the data (Brook,2003).

It is essential that all of the components in the VAR and GARCH model are stationary. However, most time series data are not stationary in their levels such that estimations based on this technique will be meaningless (spurious). Differencing the variables to mechanically turn them stationary has been a preferred approach to deal with this problem, 
but it throws away useful long run information that may be useful. These problems led to the emergence of new generation models based on cointegration and error correction modelling (Brooks, 2003:400).

There are several cointegration based methods but most of them suffer from numerous problems when applied to multivariate models. These include not being able to test for cointegration when there are multiple cointegrating relationships and sample problems amongst others. The technique in this category that has emerged as the most powerful and popular is the Johansen technique, which is the technique employed in this article.

The Johansen (1991;1995) technique has become an essential tool in the estimation of models that involve time series data. This approach is preferred as it captures the underlying time series properties of data and is a systems equation test that provides estimates of all cointegrating relationships that may exist within a vector of nonstationary variables or a mixture of stationary and nonstationary variables (Harris,1995:80).

The Johansen technique has several advantages over other cointegration based techniques, which will be discussed in the following sub-sections. The Johansen technique is preferred in this article as it allows for the estimation of a dynamic error correction specification, which provides estimates of both the short and the long run dynamics in the empirical model.

A number of steps are required in estimating the Johansen technique and these include, the need to determine the stationarity of the variables in the empirical model, the next step is performing cointegration tests in order to identify any long run relationships between the variables, a short run vector error correction model is then estimated on condition of finding cointegration in the previous step and finally, residual diagnostics tests form the last step. Impulse response and variance decomposition is performed when the variables pass the necessary diagnostics tests.

It is likely that, when a VAR includes many lags of variables, it will be difficult to see which sets of variables have significant effects on each dependent variable and which do not. In order to address this issue, tests are usually conducted that restrict all of the lags of a particular variable to zero (Brook, 2003).

However, before one proceeds to test for the rank of, $\Pi$ there are two issues that have to be attended to. The first is determining the appropriate order ( $\mathrm{k}$ ) of the VAR. Brooks (2002:404) argues that the Johansen test can be affected by the lag length employed in the VECM, thus it is crucial to attempt to select the lag length optimally. By optimally, it is meant that the chosen lag length should produce the number and form of cointegration relations that conform to all the a priori knowledge associated with economic theory (Seddighi et al., 2000:309).

On the one hand, Brooks (2002:334) states that economic theory will often have little to say on what an appropriate lag length is for a VAR and how long changes in the variables should take to work through the system. Brooks recommends the use of multivariate versions of the information criteria, which includes the sequential modified likelihood ratio (LR), Akaike information criterion (AIC), Final prediction error (FPE) Schwarz information criterion (SC) and the Hannan-Quinn information criterion (HQ). However, these information criteria usually produce conflicting VAR order selections. In light of these problems, we will use both the information criteria approach and the priori knowledge from economic theory to select the appropriate order of the VAR.

Once the appropriate VAR order $(\mathrm{k})$ and the deterministic trend assumption have been identified, the rank of the $П$ matrix can then be tested. There are two likelihood ratio (LR) test statistics for cointegration under the Johansen approach: the trace ( trace $\lambda$ ) and the maximum eigenvalue ( $\max \lambda)$ statistics, which are specified as follows:

$$
\lambda_{\text {trace }(r)=-T} \sum_{i=r+1}^{N} \ln \left(1-\lambda{ }^{i}\right) . .
$$

and

$$
\lambda_{\max }(r, r+1)=\operatorname{TIn}\left(1-\hat{\lambda}_{r+1}\right)
$$

where $r$ is the number of cointegrating vectors under the null hypothesis, $\lambda_{i}$ is the estimated value for the $i t h$ ordered eigenvalue from the $\Pi$ matrix . The trace statistic sequentially tests the null hypothesis that the number of cointegrating relations is $r$ against the alternative of $k$ cointegrating relations, where $k$ is the number of endogenous variables. The maximum eigenvalue conducts separate tests on each eigenvalue and has as its null hypothesis that there are $r$ cointegrating vectors against an alternative of $r+1$ (Brooks, 2002: 405). To determine the rank of the $\Pi$ matrix the above trace and maximum eigenvalue test statistics are compared to the (non- standard) critical values from Osterwald-Lenun (1992), which differ slightly from those originally reported by Johansen and Juselius (1990).

For both tests, if the test statistic is greater than the critical values, the null hypothesis that there are $r$ cointegrating vectors is rejected in favour of the corresponding alternative hypothesis. 
However, the trace and maximum eigenvalue statistics may yield conflicting results. To deal with this problem, Johansen and Juselius (1990),recommend the examination of the estimated cointegrating vector and basing one's choice on the interpretability of the cointegrating relations. Alternatively, Luintel and Khan (1999: 392) show that the trace test is more robust than the maximum eigenvalue statistic in testing for cointegration. The two approaches will be considered in this study when faced with such a problem.

Once the number of cointegrating vectors in the modelhave been identified, a VECM can be estimated by specifying the number of cointegrating vectors, trend assumption used in the previous step and normalising the model on the true cointegrating relation(s). Thus, a VECM is merely a restricted VAR designed for use with nonstationary series that have been found to be cointegrated. The specified cointegrating relation in the VECM restricts the long run behaviour of the endogenous variables to converge to their cointegrating relationships, while allowing for short run adjustment dynamics. The coefficients of the VECM have already been explained and they will not be repeated here. Once estimation is complete, the residuals from the VECM must be checked for normality, heteroskedacity and autocorrelation.

In order to consider further the effect of the exchange rate on unemployment, the impact multipliers that orthogonalised impulse responses should also calculated for the estimated VAR model. The forecast error variance is decomposed to determine the proportion of the movements in the unemployment rate that are a consequence of its own shocks rather than shocks to other variables. Moreover, all variables to be included in the VAR are required to be stationary in order to carry out joint significance tests on the lags of the variables. Hence, all variables are subjected to Augmented Dickey--Fuller (ADF) tests.

\section{Data}

Quarterly data covering the from period 2000 to 2010 was used in this study. The data was obtained from South African Reserve Bank (SARB), the International Financial Statistics (IFS) published by the International Monetary Fund (IMF), Johannesburg Stock exchange and Department of Trade and Industry.

Table 1: Estimation results of the GARCH Model

\begin{tabular}{|c|c|c|c|c|}
\hline \multicolumn{5}{|c|}{$\begin{array}{l}\text { Dependent Variable: LUN } \\
\text { GARCH }=\mathrm{C}(3)+\mathrm{C}(4)^{\star} \mathrm{RESID}(-1)^{\wedge} 2+\mathrm{C}(5)^{\star} \mathrm{GARCH}(-1)+\mathrm{C}(6)^{\star} \mathrm{LGDP}+\mathrm{C}(7) \\
{ }^{*} \mathrm{LEXP01}+\mathrm{C}(8)^{\star} \mathrm{LRIR}\end{array}$} \\
\hline Variable & Coefficient & Std. Error & z-Statistic & Prob. \\
\hline $\mathrm{C}$ & 1.709046 & 0.221746 & 7.707216 & 0.0000 \\
\hline LEXC & 0.080126 & 0.075430 & 1.062247 & 00000 \\
\hline \multicolumn{5}{|c|}{ Variance Equation } \\
\hline C & 0.008822 & 0.068198 & 1.829365 & 0.0000 \\
\hline $\operatorname{RESID}(-1)^{\wedge} 2$ & 1.001683 & 0.920181 & 1.788571 & 0.0000 \\
\hline GARCH(-1) & -0.206275 & 0.003222 & -1.998353 & 0.7156 \\
\hline LGDP & 0.000179 & 0.007675 & 2.023289 & 0.0002 \\
\hline LEXP01 & 0.003088 & 0.002205 & -1.600683 & 0.0001 \\
\hline LRIR & 0.000428 & 0.014322 & 1.929882 & 0.0000 \\
\hline
\end{tabular}

$\operatorname{GARCH}(-1)$ is the dependent variable and it is also the variance of the residual and represent the volatility of unemployment and in this case unemployment is not significant as the $p$ value is 0.7156 which is greater than $5 \%$ meaning unemployment is not volatile. In this case the exchange rate is the variable that is volatile as the $p$ value is significant at $5 \%$ and the volatility of the exchange rate has been captured in the variable exchange rate (LEXC) as it is indicated by its significance.

\subsection{Exchange rates (LEXC)}

Real exchange rate (LEXC) has a positive coefficient and it is statistically significant at $a<5 \%$. The coefficient of LEXC implies that a $1 \%$ increase in volatility of exchange rate will lead to $8 \%$ increase in unemployment. These results suggest that a depreciation of the rand does not necessarily reduce unemployment. 


\subsection{Exports (LEXP01)}

Exports (EXP01) have a positive coefficient and it is statistically significant $\alpha<5 \%$. This implies that as exports increase unemployment also increases.Clearly an increase in exports does not necessarily reduce unemployment.

\subsection{Real interest rates (LRIR)}

Real interest rates (LRIR) have a positive coefficient and they are also statistically significant $\alpha<5 \%$. This implies that when real interest rates increase the cost of borrowing increases meaning firms do not go and borrow as the cost of borrowing will be high and this means less investment and thereby increasing unemployment as firms will not employ.

\subsection{Gross domestic product (LGDP)}

The results in table 1 above indicate a statistically significant and positive relationship between economic growth (LGDP) and poverty $a<5 \%$. between unemployment and gross domestic product.

Hypothetically an increase in GDP should reduce unemployment but our results indicate that an increase in GDP in South Africa has not had a significant impact on unemployment reduction. However, our findings support the views of Barker (2005) who indicates that South Africa is experiencing a jobless growth and this effectively means that our growth in South Africa does not necessarily translate into unemployment reduction.

\subsection{Cointegration}

Cointegration analysis is conducted using the Johansen procedure to determine whether there is a long run equilibrium relationship between the real exchange rate and unemployment. Testing for cointegration has always given researchers a difficult task and in most cases, it has produced too many cointegrating relationships which are difficult if not impossible to interpret. As some researchers argue, the main difficulty encountered is the interpretation of cointegrating vectors which include a large number of variables.

When faced with such a problem, one option to deal with it is to estimate a simplified model with very few variables, but with the risk of an omitted variables bias. We partially follow the approach in (Aron et al,1997) estimating alternative models and using theoretical priors to achieve a parsimonious equation, but try to avoid this purely 'modelmining' exercise by using a pairwise correlation matrix to guide the variable selection exercise (Brook,2003).Table 2 below presents the pairwise correlations of the variables of our unemployment model.

Table 2: Pairwise Correlation matrix

\begin{tabular}{|l|lllll|}
\hline & LUN & LEXC & LEXP01 & LGDP & LRIR \\
\hline LUN & 1.000 & 0.036 & 0.039 & -0.0953 & -0.134 \\
LEXC & 0.036 & 1.000 & -0.221 & -0.055 & 0.119 \\
LEXP01 & 0.092 & -0.221 & 0.000 & 0.162 & -0.618 \\
LGDP & 0.095 & 0.055 & 0.162 & 1.000 & -0.413 \\
LRIR & 0.134 & 0.1195 & -0.168 & -0.413 & 1.000 \\
\hline
\end{tabular}

By looking at the pair wise correlations in Table 2 above, the following observation can be made:

There is no evidence of correlation and therefore there is no existence of multicollinearity.

The next step was to perform a vector autoregression on the above variables. Before the researcher estimated equations, she had to decide on the maximum lag length $\mathrm{k}$ considering that too many lagged terms consume degrees of freedom, needless to mention the possibility of multicollinearity. Brooks (2003) argues that the Johansen test can be affected by the lag length employed in the VECM, thus it is crucial to attempt to select the lag length optimally. By optimally, it is meant that the chosen lag length should produce the number and form of cointegration relations that conform to all the a priori knowledge associated with economic theory.

Including too few lags will lead to specification errors. One way of deciding this question was to use the Akaike or Schwarz criterion and choose a model that gives the lowest values of these criteria. On the other hand, Brooks (2003:334) argues that economic theory will often have little to say on what an appropriate lag length is for a VAR and how long changes in the variables should take to work through the system. 
Brooks recommends the use of multivariate versions of the information criteria, which includes the sequential modified likelihood ratio (LR), Akaike information criterion (AIC), Final prediction error (FPE) Schwarz information criterion (SC) and the Hannan-Quinn information criterion (HQ). However, these information criteria usually produce conflicting VAR order selections. In light of these problems, the researcher will use both the information criteria approach and the a priori knowledge from economic theory to select the appropriate order of the VAR.

Table 3 below shows the lag length criteria obtained from the unrestricted VAR. The information criterion approach produces results which indicate a choice of lag 1 . An optimal lag length is required to produce uncorrelated and homoskedastic residuals.

Table 3: Lag Length information criterion

\begin{tabular}{ccccccc}
\hline \hline Lag & LogL & LR & FPE & AIC & SC & HQ \\
\hline \hline 0 & 32.67374 & NA & $1.84 \mathrm{e}-07$ & -1.317797 & -1.110932 & -1.241973 \\
1 & 177.9692 & $249.0779^{\star}$ & $6.05 \mathrm{e}-10^{\star}$ & $-7.046151^{*}$ & $-5.804959^{\star}$ & $-6.591205^{\star}$ \\
2 & 202.9333 & 36.85181 & $6.39 \mathrm{e}-10$ & -7.044443 & -4.768923 & -6.210375 \\
\hline \hline
\end{tabular}

* indicates lag order selected by the criterion

LR: sequential modified LR test statistic (each test at $5 \%$ level)

FPE: Final prediction error

AIC: Akaike information criterion

SC: Schwarz information criterion

HQ: Hannan-Quinn information criterion

Based on the information given in table above the maximum lag length chosen is $=1$. Having chosen the maximum lag length the next step was to test for Cointegration amongst variables.

\subsection{Test for Cointegration}

Cointegration analysis was conducted using the Johansen procedure to determine whether there is a long run equilibrium relationship exchange rate volatility and unemployment. The procedure involved specifying the optimal leg length and choosing of the deterministic assumption that the Johansen test requires.

Unrestricted Cointegration Rank Test (Trace)

\begin{tabular}{ccccc}
\hline \hline $\begin{array}{c}\text { Hypothesized } \\
\text { No. of CE(s) }\end{array}$ & Eigenvalue & $\begin{array}{c}\text { Trace } \\
\text { Statistic }\end{array}$ & $\begin{array}{c}0.05 \\
\text { Critical Value }\end{array}$ & Prob.* $^{*}$ \\
\hline \hline None & 0.627836 & 87.01918 & 69.81889 & 0.0012 \\
At most 1 & 0.490422 & 46.49395 & 47.85613 & 0.0667 \\
At most 2 & 0.244424 & 18.85287 & 29.79707 & 0.5035 \\
At most 3 & 0.147447 & 7.361568 & 15.49471 & 0.5360 \\
At most 4 & 0.019831 & 0.821233 & 3.841466 & 0.3648 \\
\hline \hline
\end{tabular}

Trace test indicates 1 cointegrating eqn(s) at the 0.05 level

* denotes rejection of the hypothesis at the 0.05 level

**MacKinnon-Haug-Michelis (1999) p-values

Unrestricted Cointegration Rank Test (Maximum Eigenvalue)

\begin{tabular}{ccccc}
\hline \hline $\begin{array}{c}\text { Hypothesized } \\
\text { No. of CE(s) }\end{array}$ & Eigenvalue & Max-Eigen & 0.05 \\
Critical Value & Prob. $^{* \star}$ \\
\hline \hline None & & Statistic & 33.87687 & 0.0070 \\
At most 1 & 0.627836 & 40.52523 & 27.58434 & 0.0492 \\
At most 2 & 0.490422 & 27.64108 & 21.13162 & 0.5983 \\
At most 3 & 0.244424 & 11.49130 & 14.26460 & 0.5449 \\
At most 4 & 0.147447 & 6.540335 & 3.841466 & 0.3648 \\
\hline \hline
\end{tabular}

Max-eigenvalue test indicates 2 cointegrating eqn(s) at the 0.05 level

* denotes rejection of the hypothesis at the 0.05 level

**MacKinnon-Haug-Michelis (1999) p-values 
The top part of the table above represents the Trace test whilst the bottom part represents the Maximum Eigenvalue test. Starting with the trace test, the null hypothesis of no cointegrating vectors is rejected, since the test statistic of about 87.01 is greater than the $5 \%$ critical value of approximately 69.82 . In the same way, the null hypothesis that there are at most 1 cointegrating vectors is rejected, but the null hypothesis that there are at most 2 cointegrating vectors cannot be rejected, since the test statistic of approximately 18.85 is less than the $5 \%$ critical value of about 29.80 . The Trace test indicates cointegrating eqn(s) at the 0.05 level.

The bottom part of table above shows the Eigenvalue test. The maximum eigenvalue form of the Johansen test also rejects the null hypothesis of no cointegration, but reject that of at most 1 cointegrating vectors, since the test statistic of about 27.64 is now less than the 5 per cent critical value of about 27.58 The Maximum Eigenvalue test results indicate that there is a cointegrating relationship in the empirical model at the 0.05 level. We therefore can run any vector error correction model.

The trace test is more robust than the maximum eigenvalue form of the Johansen test. However, we do not take this as a given, but use the results of each test and let a priori theoretical knowledge guide us in selecting the cointegration rank. We estimated VECMs restricted on 1 and 2 cointegrating vectors separately, as chosen by the maximum eigenvalue and trace test, respectively. Results from the estimations confirm Luintel and Khan's (1999: 392) finding that the trace test is more robust than the maximum eigenvalue test, since 1 cointegrating relationship chosen by the trace test does not produce economically meaningful results. We therefore conclude that there are 2 cointegrating relationships in our model. Another interesting conclusion from this analysis is that there are cointegrating relationships between I(0) and I(1) variables, thus corroborating Harris's (1995: 80) finding that variables integrated of different orders may be cointegrated. What remains is to identify which 2 cointegrating vectors represent the true cointegrating relationships.

The number of cointegrating relationships obtained in the previous step, the number of lags and the deterministic trend assumption used in the cointegration test are all used to specify a VECM. The VECM results for our main model, are presented in table 4 below

Table 4: VECM Results

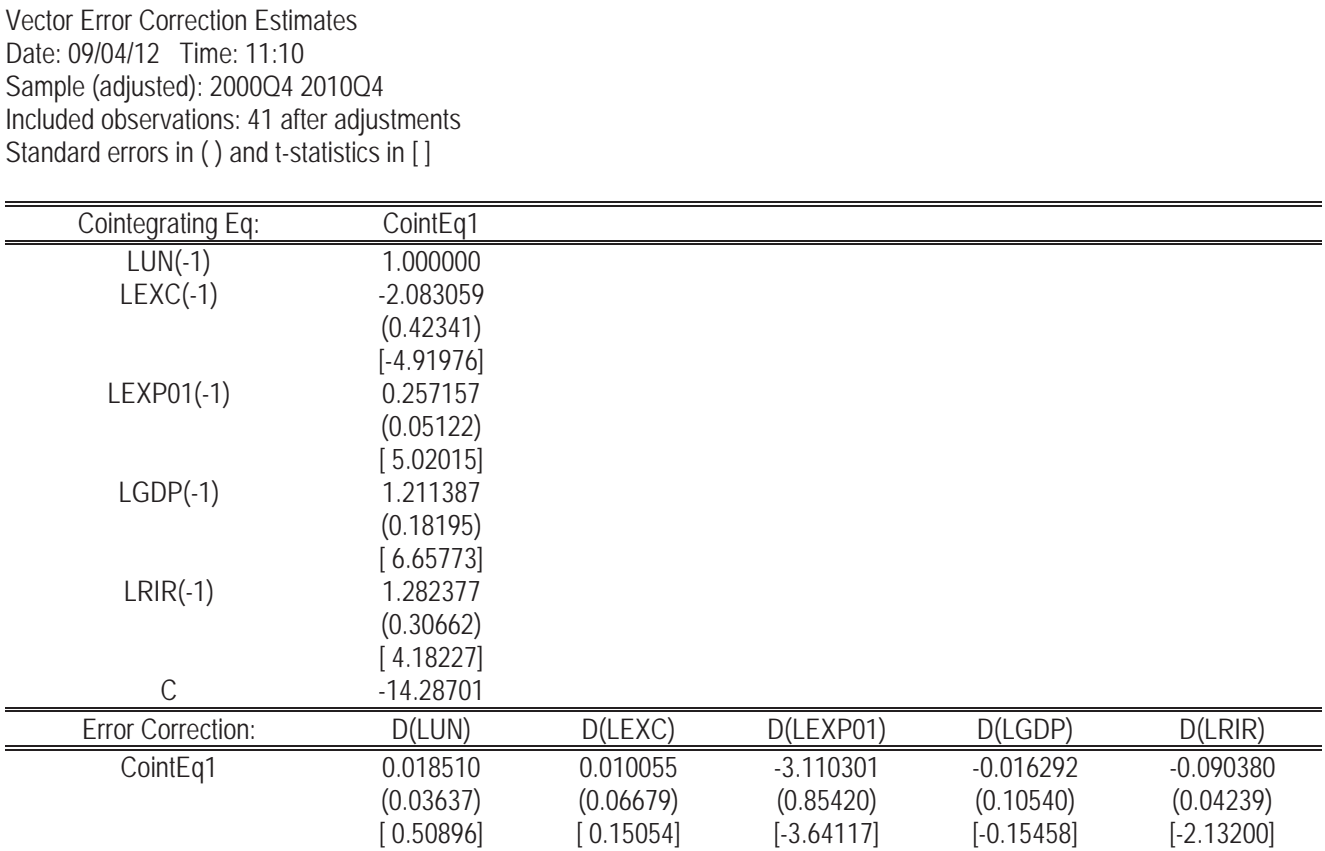

A comparison of the coefficients of the error correction terms (cointEq1 for the first vector shows that LEXP01 and LRIR has the most significant coefficient, with a t-value of -3.64117 and -2.13200 respectively and LEXP01 has a correct 
negative sign. Other variables however either have a wrong sign or are less significant. This suggests that exports and real interest rates constitute the true cointegrating relationship in the first cointegrating vector. Our conclusion is supported by the plot in the graph below showing the first vector in the cointegration space, which appears to be stationary.

Figure 1. Cointegration graph for unemployment rate equation

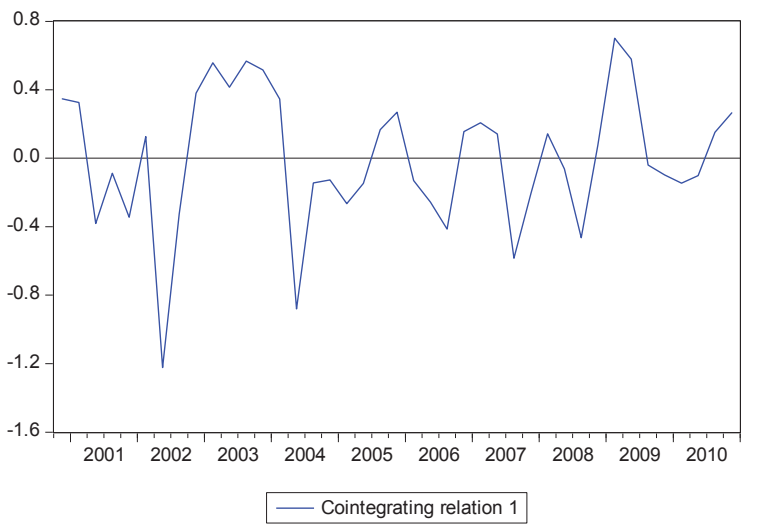

Real interest rate has a positive long-run relationship with unemployment rate, as indicated by the significance of its coefficient. This means that an increase in real interest rates in South Africa will increase unemployment. These results do not corroborate the theoretical predictions that an increase in real interest rates in South Africa will also increase unemployment in the long run. It is only in the short run that an increase in real interest rates leads to a reduction in unemployment.

Exchange rate has a negative coefficient in the long run meaning the depreciation of the rand leads to the reduction in unemployment in the long run. However, in the short run the results show an opposite effect in that a weak currency does not translate into employment creation. VECM results show a positive relationship between exchange rates and unemployment.

GDP has a positive coefficient in the long run as indicated by the significance of its coefficient. This means that an increase in GDP in South Africa will result in an increase in unemployment. It is only in the short run that GDP seems to reduce unemployment. These results are in line with Barker (2005) who indicates that South Africa is experiencing a jobless growth and this effectively means that our growth in South Africa does not necessarily translate into unemployment reduction.

The relationship between exports and unemployment is statistically significant both in the short run and long run. However, exports have a positive coefficient meaning that an increase in exports does not necessarily decrease unemployment in South Africa in the long run. When examining this relationship in the short run, exports have a negative impact meaning that it is only in the short run that exports are effective in creating jobs.

The GARCH results indicated that real exchange rates, exports, gross domestic product and real interest rates all have a positive impact on unemployment. Johansen cointegration tests on alternative model specifications provided evidence that there is cointegration between the unemployment its determinants, which were included in those models. This finding, therefore, indicates that unemployment rate is subject to permanent changes as a result of changes in its fundamentals.

Evidence of cointegration allowed the estimation of VECMs, which simultaneously provided the parameter estimates for both the long and short run relationships. The variables that have a long run relationship with unemployment include the real exchange rate, real interest rates, gross domestic product and exports. An increase in the real exchange rate, real interest rates, exports and gross domestic product all increase unemployment. These results, therefore, corroborate the theoretical framework to a large extent. Another interesting parameter in VECMs is the speed of adjustment coefficient which, in this study, measures the speed of adjustment in the unemployment rate following a shock in the system.

The short run dynamics from the VECMs suggested that only real interest rates and exports are significant in influencing unemployment. However, a better picture of the short run dynamics emerged from the impulse response and 
variance decomposition analyses. The latter tests provided evidence that the exchange rate, exports and real interest rates have a significant impact on unemployment. However, only shocks to terms of the real exchange rate and interest rates have persistent effects on the real exchange rate. Another interesting result which emerged from this analysis which is supported by previous research is that among other determinants, the real exchange rate explains the largest proportion of the variation in unemployment.

\section{Conclusions}

The econometric results in this article show that an increase in real exchange rate has adverse effects on employment. A stable currency is generally good for trade, as it makes business more predictable, reduces risks and means that consumer prices can be kept stable hence artificially high exchange rate can put exporters at a disadvantage.

Based on the outcome of this research the hypothesis that the exchange rate volatility has a negative impact on the South African labour market cannot be rejected.

\section{Acknowledgements}

Several people have contributed in the production of this article. I would like to express my sincere gratitude to my supervisor Professor Ncwadi for his invaluable advice and encouragement. My gratitude is also importantly extended to my husband, Jeremiah Singizi, who did not only read this work, but also provided the vital encouragement at the outset, without which the article would never have been written. Lastly but not least I want to forward my humble and heartfelt gratitude to the Nyahokwe family and my son Shaun.

\section{$\underline{\text { References }}$}

Accelerated and Shared Growth Initiative for South Africa (Asgisa). [Online] Available : http://www.info.gov.za/asgisa lasgisa.htm.Accessed on 22/04/2012

Adjasi, C. (2008). Effect of Exchange rate volatility on the Ghana stock exchange. African Journal of Accounting, Economics and banking research Vol.3. No. 2008.

Aizenman, J., and Marion, N. (1999). Volatility and Investment: Interpreting evidence from Developing Countries. Economica.

Alexander, C. 2008. Market Risk Analysis: Practical Financial Econometrics John Wiley and Sons.

Andersen, T. B., and Sorensen, J. R. (1988). Exchange rate variability and Wage formation in Open Economies. Economic Letters.

Apergis, N. (2000) Employment news and exchange rates: policy implications for the European union. Applied Economics Letters, 7 , 695-8.

Arize, A. C. and Shwiff, S. S. (1998) Does exchange-rate volatility affect import flows in G-7 countries? Evidence from cointegration models, Applied Economics, 30, 1267-76.

Arouri, M.E.H and Jawadi, D.K. The dynamics of emerging stock markets: Empirical Assessments and Implications. London. Springer

Ball, Lawrence (1997), "Disinflation and the NAIRU", in Reducing Inflation: Motivation and Strategy, ed. by Romer, Christina and David Romer, University of Chicago Press.

Ball, Lawrence (1999), "Aggregate Demand and Long-Run Unemployment", Brookings Papers on Economic Activity, 2, 189-236.

Ball, L. and Mankiw, N. G., (2002), "The NAIRU in Theory and Practice.Harvard Institute of Economic Research Working Papers 1963. Harvard - Institute of Economic Research.

Belke, A. and Gros, D. (2002) Designing EU-US Atlantic monetary relations: exchange rate variability and labour markets, The World Economy, 25, 789-813.

Belke, A., and Gros, D. (2002). Designing US-EU Monetary Relations: The Impact of Exchange Rate Variability on Labor Markets on both sides of the Atlantic. The World Economy.

Belke, A., and Kaas, L. (2004). Exchange Rate Movements and Employment Growth: An OCA assessment of the CEE economies. Empirica.

Branson, W., and Love, J. (1988). United Sates Manufacturing and the Real Exchange Rate. In R. Marston (Ed.), Misalignment of Exchange Rates: Effects on Trade and Industry. University of Chicago Press.

Branson W.H and Love J.P (1988).U.S Manufacturing and the Real Exchange Rate in Marston R.C.(ed) Misalignment of the Exchange Rates: Effects on Trade and Industry. University of Chicago Press.

Brooks, C. 2003. Introductory Econometrics for Finance. Cambridge University Press :UK

Burgess S and Knetter M. 1996. "An International Comparison of Employment Adjustment to Exchange Rate Fluctuations". NBER Working Paper 5861 (December).

Burgess, S. M., and Knetter, M. M. (1998). An International Comparison of Employment Adjustment to Exchange Rate Fluctuations. Review of International Economics, 6 (1), pp. 151-163. 
Campa, M. J., and Goldberg, L. S. (2001). Employment versus Wage Adjustment and the U.S. Dollar. The Review of Economics and Statistics, 83 (3), 477-489.

Dekle, R. (1998). The Yen and Japanese Manufacturing Employment. Journal of International Money and Finance, 17, $785-801$.

Darby, J., Hughes Hallett, A., Ireland, J., Piscitelli, L., 1999. The Impact of Exchange rate on Unemployment in Asia: World Development .Vol. 45

Dixit, A., and Pindyck, R. S. (1994). Investment under Uncertainty. Princeton, New Jersey: Princeton University Press.

Donner, R.V and Barbosa, S.M., 2008. Non-Linear Time Series Analysis in the Geosciences. Germany, Springer.

Dornbursch R and Fischer S., 2008. Macroeconomics. (10e) New York: McGraw- Hill Companies.

Dowd, K. 2005. Measuring Market Risk. New York, John Wiley and Sons.

Du Plessis, S. and Smith, R., (2007), "A New Keynesian Phillips Curve for South Africa", SARB Conference 2006.

Economist Intelligence Unit (EIU)., (2007). South Africa: Country Profile 1992-1993. London: The Economist Intelligence Unit.

Engle, R. F., and Granger, C. W. J., (1987) "Co-integration and Error Correction: Representation, Estimation, and Testing", Econometrica, 55, 2, 251-276.

Evans, M.K., 2003. Practical Business Forecasting. UK, Blackwell Publishing Company.

Farag, H., 2009. Collaborative Value Creation: An Empirical Analysis of the Europena Biotechnology Industry. Germany, Springer.

Fischer, S., (1977), "Long-Term Contracts, Rational Expectations, and the Optimal Money Supply Rule, "Journal of Political Economy, 85, 191-205.

Florin, E., 2010. Causality Measures between neural signals from invasively and non-invasively obtained local field potentials in humans. Forschungszentrum. Netherlands.

Frankel, J. A., and Romer, D. (1999). Does Trade Cause Growth. The American Economic Review, 89 (3), 379-399.

Frenkel, Jaime ros. (2006). Unemployment and the Real Exchange Rate in Latin America. World Development, Vol. 34, No. 4, pp. 631646.

Frenkel,R and J. Ros (2005).Unemployment and the Real Exchange Rate in Latin America .World Development, Vol.34

Friedman, M.,1986. The Role of Monetary Policy. New York, USA: American Economic Review 58.

Gillespie, A., 1998. Economics through diagrams. New York: Oxford University Press

Goldberg and Tracy. (1999). Exchange Rates and Local Labor Markets. Federal Reserve Bank of New York and NBER.

Granger, C. and Newbold, P., (1974), "Spurious regressions in econometrics", Journal of Econometrics, 2, 111-120.

Gujarati, D.N. 2004 .Basic Econometrics. 4th edition. McGraw-Hill: New York.

Harris, R., 1995. Using cointegration analysis in econometric modelling. London: Prentice Hall.

Hofmeyr, J. 2012. Transformation Audit 2011. From inequality to Inclusive Growth. Cape Town, Institute for Justice and Reconciliation.

IMF. 2012. South Africa: Selected Issues. Washington, IMF

Kadir, H.B.A., Selamat, Z., Masuga, T., Taudi, R. 2011. Predictability Power of Interest Rate and Exchange Rate Volatility on Stock Market Return and Volatility: Evidence from Bursa Malaysia. International Conference on Economics and Finance Research IPEDR vol.4 (2011) IACSIT Press, Singapore

Kim, W. (2005), Analyses of the Relationship between Exchange Rates and Employment in Korea .Journal of Economic Development, Vol.30.

Knight.J.L and Stchell, S. 2007. Forecasting Volatility in the Financial Markets. Butterworth-Heinemann, United Kingdom

Korsgaard, J.K. 2009. Stock Returns and Exchange rate Volatility. The Aarhus School of Business

Kroner K F and Lastrapes W D. 1993. "The Impact of Exchange Rate Volatility on International Trade: Reduced-form Estimates Using the GARCH-in-Mean Model", Journal of International Money and Finance 12; 298-318.

Lipsey, R. G and Crystal A, K, 2007. Economics (11e). New York: Oxford University Press Inc

Lucas, Roberte E., 1976. Econometric Policy Evaluation. New York: Oxford University press Inc.

Luintel, K. B. and Khan, M., 1999. A quantitative reassessment of the finance-growth nexus: evidence from a multivariate VAR. Journal of Development Economics. 60: 381-405.

Lutkepohl, H. and Reimers, H. E., 1992. Impulse response analysis of a cointegrated system. Journal of Economic Dynamics and Control.16: 53-78.

MCcallum, Bennett T., 1976. Econometrica. New York: Haucourt Brace Javanoric.

Mcconnell, C.R. and Brue, S.L., 1996. Macroeconomics (14e). USA: McGraw-Hill, Inc Malliaropulos, Dimitrios (1998), International Stock Return Differentials and Real Exchange Rates Changes, Journal of International Money and Finance, 17, pp.493-511.

McKenzie M D. 1999. "The Impact of Exchange Rate Volatility on International Trade Flows", Journal of Economic Surveys Vol.13, No.1: 71-106.

Mellander, E., Vredin, A. and Warne, A., 1992. Stochastic trends and economic fluctuations in a small open economy. Journal of Applied Econometrics. 7: 369-394.

Mernard, S.W. 2008. Handbook of Longitudinal Research: Design, Measurement and Analysis. United Kingdom, Elsevier Inc

Mishkin, F. S., 2006. The economics of money, banking and financial markets (7e). New York: Addison-Wesley.

Mobarak, A. M. (2005). Democracy, Volatility and Economic Development. Review of Economics and Statistics.

Mun, J. 2010. Modelling Risk: Applying Monte Carlo Risk Simulation, Strategic Real Options Stochastic Forecasting and Portfolio Optimisation. Canada John Wiley and Sons. 
Munyama, T.V. and Todani, K.R., 2007. Exchange Rate Volatility and Exports in South Africa: Trade and Uneven Development: Opportunities and Challenges. South African Reserve Bank. Available: <http://www.tips.org.za/node/411> Accessed on 30/02/2012

Natrass N (1994) Macroeconomics, Theory and Policy in South Africa, Claremont south Africa, David Philip publishers.

Ngandu S (2008) Sectoral: Impact of the Exchange rate on Employment Economic Growth and Development: Initiative Working Paper, HSRC

Nicholas Apergis. (2000). Employment News and Exchange Rates: Policy Implications European Union. Applied Economics Letters.

Nucci and Pozzolo (2004). The Effects of Exchange Rate Fluctuations on Employment, University's di Roma - La Sapienza, University's del Molise. University's di Roma "La Sapienza, University's del Molise.

Omojimite,B.U., and Akpokodje, G. 2010. The Impact of Exchange Rate Reforms on Trade Performance in Nigeria. [Online] Available: http://www.krepublishers.com/02-Journals.

Pallage, S., and Robe, M. A. (2003). On the Welfare Cost of Economic Fluctuations in Developing Countries. International Economic Review.

Pattichis, Cheongz, et al . (2004). Exchange Rate Uncertainty, UK trade and the Euro .Applied Financial Economics , 14, $885-893$.

Phillips, A. W., 1958. Econometrica 25e. United Kingdom: McGraw- Hill Inc.

Philip A. Black, Satin Calitz, Tjaart.J.Steenekamp and associates., 1999. Public Economics. South Africa: Oxford University Press.

Piot-Lepeti, I., and M'Barek, R. 2011. Methods to Analyze Agricultural Commodity Price Volatility. Springer, London.

Revenga, A. (1992, Feb). Exporting Job? The Impact of Import Competition on Employment and Wages in US Manufacturing. Quarterly Journal of Economics , 107 (1), pp. 255-284.

Rodrik, D (2004) 'Industrial policy for the twenty-first century', Discussion Paper No. 4767. London: Center for Economic Policy Research.

Ron,J., Elbadawi, I. A. and Kahn B., 2000. Real and monetary determinants of the real exchange rate in South Africa. In: Elbadawi, I. and Hartzenberg, T. (eds). Development Issues in South Africa. London: Macmillan.

Sarkar, A. 2012. Functional Stability or Paradigm Shift?; A characteristic study of Indian Stock Market in the 1st Decade of the New Millennium. India, Springer

Sarris and Hallan,2006:202. Agricultural Commodity Markets: New Approaches to Analysing Market Structure and Instability. Edgar and Elgar Publishing, UK

Schoeman, C.H. and Blaauw, P.F., (2005), "High levels of unemployment: A long-run reality for South Africa", Paper presented at the ESSA Bi-annual Conference, Durban, 7-9 September 2005.

Serven, L. (1998). Macroeconomic Uncertainty and Private Investment in Less Developed Countries: An empirical investigation. The World Bank Policy Research Working Paper 2035.

Snowdon Brian, Vane H R (2003) Modern Macroeconomics: Origins, development and current state.UK, Edward Elga Publishing limited. StatsSA. (2012).Key indicators . Available Online. www.statssa.gov.za/keyindicators/gdp.asp. Accessed 22/03/2012

Takaendesa, P., 2006. The behaviour and fundamental determinants of the real exchange rate in South Africa. Rhodes University.

Trichet,J.,C 2010.Currency Volatility Threatens Growth. [Online]. Available: http://finance http://finance.yahoo.com /news/Currencyvolatility-threatens -apf-2463389433.html.Accessed 10/05/2012

Van Der Merwe, E., and Mollentze, S. 2009. The Monetary Economics of South Africa. South Africa Oxford University Press.

Wasen, S., and Lehmann, F.N. 2009. Poverty, Inequality and Policy in Latin America. USA, Massachusetts Institute of Technology.

World Bank (2005) An Investment Climate Assessment for South Africa. Washington DC: World Bank. Accessed at http://www1,worldbank.org/rped/index.asp? page=icas

World Bank. 2007. www.worldbank.org. Available online. Accessed on 01/03/2012

Yanhui and Wang. (2006). The Effect of Changes in Real Exchange Rates on Employment: Evidence from Manufacturing Industries in China. Higher Education Press and Springer-Verlag. 